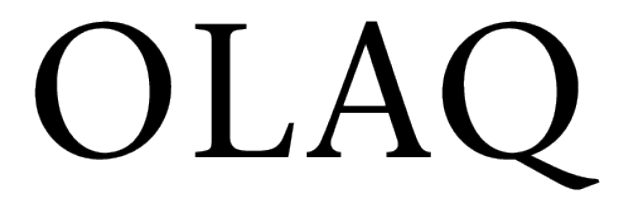

Volume 23 , Number 2 Critical Librarianship | Pages 19 - 23

$10-6-2017$

\title{
Critically Interrogating Oregon History in the Archives: Spanish Heritage Learners in the PCUN Records
}

David Woken

University of Oregon

Follow this and additional works at: http://commons.pacificu.edu/olaq

Part of the Archival Science Commons, Cataloging and Metadata Commons, Collection Development and Management Commons, Education Commons, Information Literacy Commons, Latin American Languages and Societies Commons, and the Reading and Language Commons

Woken, D. (2017). Critically Interrogating Oregon History in the Archives: Spanish Heritage Learners in the PCUN Records. OLA Quarterly, 23(2), 19-23. https://doi.org/10.7710/1093-7374.1896

(C) 2017 by the author(s).

OLA Quarterly is an official publication of the Oregon Library Association | ISSN 1093-7374 | http://commons.pacificu.edu/olaq 


\section{Critically Interrogating \\ Oregon History in the Archives: Spanish Heritage Learners in the PCUN Records}

\section{by David Woken}

History and Latin American

Studies Librarian \& Coordinator

of Graduate Instruction,

University of Oregon Libraries

dwoken@uoregon.edu

@DavidWoken

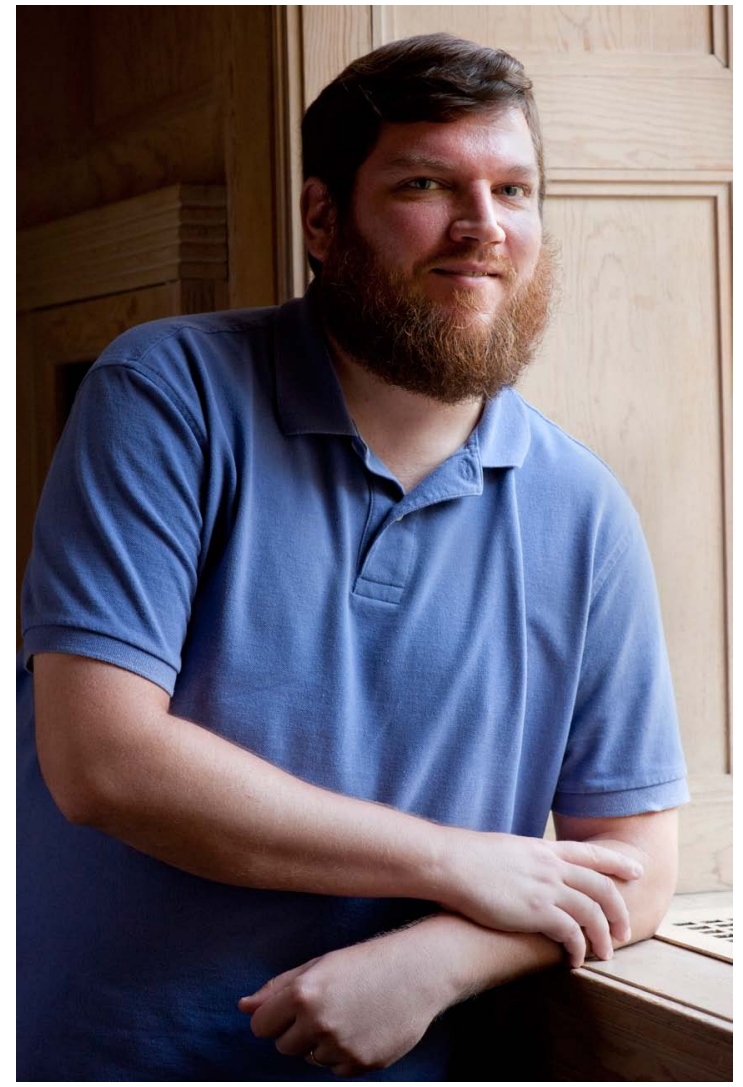

David is the History and Latin American Studies Librarian and Coordinator of Graduate Instruction at the University of Oregon Libraries. He is also the curator of the archival collections on Latinx history housed in UO Libraries' Special Collections and University Archives, particularly the records of the Oregon farmworker union Pineros y Campesinos Unidos del Noroeste (Northwest Tree Planters and Farmworkers United, PCUN). He received his MA in Library and Information Studies from the University of Wisconsin-Madison and his MA in Latin American History from Indiana University. His research interests include the history of Oregon's Latinx community and the use of critical pedagogical methods with historical primary source materials.

DAVID WOKEN

Critical librarianship has emerged over the past decade or so as one of the main thrusts of the library profession's longstanding commitment to social justice. Growing from the application of insights from critical theory to libraries as an institution, the critical librarianship movement explores how hierarchies of power, particularly those around race, gender, sexuality, and class, shape our work, and how we can challenge our profession's complicity in those hierarchies. Critical librarianship's insights have been applied perhaps most thoroughly in the areas of cataloging and classification and, especially, information literacy instruction (Garcia, 2015). Critical information literacy instruction has spread rapidly through the library profession, and its influence is noticeable in the Association of College and Research Libraries' "Framework for Information Literacy for Higher Education" (2016), with its emphasis on critical examination of the construction of texts and their role within systems of power. Drawing on the critical pedagogy tradition of the Brazilian organizer and adult literacy educator Paolo Freire and the U.S.-based critical educational theorist Henry Giroux, critical information literacy instruction focuses on teaching as a dialectical process wherein the instructor is a facilitator in dialogue with their students, working with them in a process of critical interrogation of texts where all participants learn from one another's experience (Gage, 2004). Instructor and student work together to unpack the ways that their texts, be 
they a primary source, a published scholarly study, or a searchable database, are shaped by and embedded in systems of power. This process facilitates critical thinking, but also, when done effectively, leads to an understanding of how institutions and structures of power function. From there, we can begin to challenge those structures of power through engagement in collective democratic struggle, confronting labor exploitation, disenfranchisement, denial of social services, and other injustices by participating in social movements that advocate for the students' communities.

Here at the University of Oregon (UO) I have applied insights from critical information literacy pedagogy, as well as the literature of History pedagogy and archival instruction, to work we perform with the Spanish Heritage Language Program (SHL) in the UO Department of Romance Languages. SHL is a program of courses for students who already have significant experience with Spanish, generally native speakers, but who have not had formal instruction in the language. Put simply, it is akin to the English instruction that universities have for native English speakers, only aimed at native Spanish speakers. The SHL program at the UO, however, builds in critical perspectives on the racism, gender relations, and class exploitation that U.S. Latinx communities have faced, and the ways that culture and language reinforce those systems of exploitation and power. The program embraces the language of U.S. Spanish speakers, including code switching and "Spanglish" usage that are frequently discouraged in more prescriptive language instruction programs. It encourages students to recognize their own language and culture as legitimate and, by critically examining the sociolinguistic roles of different registers (from the formally academic or professional to informal slang), to better understand, negotiate, and challenge cultural hierarchies of power. The texts used in the classes are drawn from as wide a range of U.S. and Latin American Spanish practice as possible, from high literature to popular culture (I guest lectured in one class about U.S. Latinx rock 'n' roll and punk rock, for example) to historical primary source materials. It is to this last subject that I will turn my focus.

The Special Collections and University Archives (SCUA) at the UO Libraries houses several collections of primary sources on the history of Oregon's Latinx community. The largest and most extensive of these is the PCUN Records, the archives of the Pineros y Campesinos Unidos del Noroeste (Northwest Treeplanters and Farmworkers United, PCUN), a farmworker union based in Woodburn, Oregon. PCUN is the largest Latinx social movement organization in the state. The PCUN records document nearly 50 years of Latinx social movement organizing in the Willamette Valley, stretching from the Chicano Movement of the late 1960s-1970s up to this decade. The founders of PCUN had led the Willamette Valley Immigration Project, an immigrant legal aid organization active from 1977 to 1985 , before expanding their work into labor and community organizing by founding PCUN in 1985. PCUN has been a strong advocate for Oregon's Latinx community throughout their existence and has helped to found many other social organizations, including Causa, Oregon's immigrant rights organization; the Farmworker Housing Development Corporation, which builds affordable housing for farmworkers; the CAPACES Leadership Institute, a youth leadership training and mentorship program; and KPCN-LP "Radio Movimiento," a low power FM radio station broadcasting from PCUN's union hall in Woodburn. PCUN has also been a consistent ally of other progressive organizations, teaming up with environmental organizations to challenge pesticides, aligning with fellow 


\section{Primary Source Questions Used in the PCUN Records Sessions}

1. Look at the physical nature of your source. What can you learn from the form of the source? (Was it written on fancy paper in elegant handwriting, or on scrap-paper, scribbled in pencil?) What does this tell you?

2. Think about the purpose of the source. What was the author's message or argument? What was he/she trying to get across? Is the message explicit, or are there implicit messages as well?

3. How does the author try to get the message across? What words does he/she use to communicate their point?

4. What do you know about the author? Race, sex, class, occupation, religion, age, region, political beliefs? Does any of this matter? How?

5. Look at the above clues to determine: who constituted the intended audience? Was this source meant for one person's eyes, or for the public? How does that affect the source?

6. What can a careful reading of the text (even if it is an object) tell you? How does the language work? What are the important metaphors or symbols? What can the author's choice of words tell you? What about the silences-what does the author choose NOT to talk about? labor unions, and working alongside Basic Rights Oregon to challenge anti-immigrant and homophobic legislation and ballot measures in Oregon during the 1990s (it is worth noting that that PCUN began working to uphold LGBTQ rights long before most of their fellow unions were willing to do so). As a collection containing many Spanish-language documents showing the history of democratic, communitybased struggles by members of Oregon's Latinx community to challenge systems of racial hierarchy and class exploitation to which they have been subjected, the PCUN Records are an ideal base from which to draw texts for the type of critical pedagogical project that animates UO's SHL program.

Students come to the class with some preparation for the material, generally having read a short encyclopedia entry on PCUN (Woken, 2014) and excerpts from Lynn Stephen's short history of PCUN (Stephen, 2012) or Mario Sifuentez's history of farm labor in Oregon since WWII (Sifuentez, 2016). They then come to SCUA's classroom, where a selection of primary source documents in Spanish from the PCUN records as well as some photos, pins, flags, and other graphic materials and ephemera, are available to peruse. The students receive a brief introduction to SCUA and to archives in general before they are given a list of questions they will use to discuss the sources they see before them (see sidebar). They then work in groups of two or three to examine one of the selected texts, with the course instructor and myself there to answer questions. Discussion occurs in a fluid mix of English and Spanish. Students explore why the creators of their document chose certain language, taking into consideration the creator, audience, and other influences that would shape a document.

One fruitful piece from the collection that we use for every SHL class is a comic book written as an orientation for new union members, called Somos la unión! Some students immediately assume that the work is for children of farmworkers. However, as they examine it they realize the material in it, which includes detailed discussions of how to respond to pesticide poisoning, discussions of how union contracts work, and the occasional swearing, is hardly appropriate for children, and so they begin to think about why PCUN might have chosen to use a comic rather than a purely text document. Since many farmworkers are not well educated and all of them work long, exhausting hours at physically taxing labor, a comic is an excellent choice, being easy to read in the little downtime farmworkers have and easy to share with their fellow workers. Another fundamental lesson for many of the students is the fact that, despite their marginalization in mainstream media and curriculum, the Latinx communities of Oregon have played a cru- 
cial role in shaping the state we live in today and challenging the injustices they have faced throughout the state's history. Both for SHL students native to Oregon and those who came to UO from out of state and face the brutal culture shock that many people of color experience upon moving to Eugene, it can be powerful simply to have the life and history of Latinx people in Oregon centered in their education.

At the same time, as mentioned above, we approach the discussion as a dialectical process where we learn from our students. Many of the students are from Woodburn and have experience with PCUN, and so help to approach the lived experience of being part of the movement with their own memories of visiting the union hall and living the vibrant social and cultural life of the movement. Some students recognize friends and family in the photos from the archive and help us to fill in information that is not always obvious from the texts themselves. Many farmworkers in Oregon are not native Spanish speakers but rather communicate in Mixteco, Zapoteco, Triqui, or any number of other languages spoken in the indigenous communities of southern Mexico. Students have helped us to identify the languages used in some of the documents, as in the case of one student who helped to identify a Mixteco document when she recognized the phonetically spelled words her grandmother spoke when she was a child. In addition, the students' close reading of sources, informed by the details in the secondary sources they read before the class (Sifuentez (2016), based heavily in oral history, is particularly fruitful), have helped to further flesh out elements of documents that we otherwise may have missed. We instructors learn from our students' life experiences and so gain a richer understanding of the history we are preserving. At its best, the division between the (expert) instructor and the (amateur) student begins to break down as we learn through a mutual process to understand and appreciate the farmworker experience here in Oregon and to challenge received histories of white supremacy, patriarchy, and capitalist exploitation in favor of a bottom-up understanding of Oregon's history.

This is not to say that any of this process is easy. The ideal dialectical exchange between instructor and student does not always occur, putting us in constant dialectical engagement with our own practice. The SHL instructors and I are constantly adjusting our discussion plans as we go, tweaking our approaches to foster student leadership in the learning process. It can be a frustrating process, but the results are worth the struggle. Students have told us that they leave feeling that they have been presented with history relevant to their experience for the first time in the university, or even in all of their education. Students of color frequently feel alienated and isolated by an academy that remains steeped in whiteness, downplaying, misrepresenting, or erasing those students' experience even in the midst of declarations to uphold values of diversity, equity, and inclusion. Critical pedagogical methods, which encourage students to interrogate the relations of power and exploitation within which knowledge is embedded, provide a means for marginalized communities to challenge the oppressive systems they face. As interest in critical pedagogy continues to grow within the library profession, we must continually challenge ourselves to ensure that the liberatory potential of these methods is not neutralized and that the foundation of challenging entrenched relations of power and exploitation does not become yet another empty statement of intent in our universities that remain in many ways based in institutions of white supremacy. The challenge critical pedagogy poses to us is to act in such a way that our students in turn challenge privilege and power, including that of the faculty at the university, so 
that they can face the world as protagonists in their own struggle and, hopefully, change it in a just and equitable way.

\section{References}

Association of College and Research Libraries. (2015, February 9). Framework for Information Literacy for Higher Education. Association of College and Research Libraries. Retrieved from http://www.ala.org/acrl/standards/ilframework

Gage, R. A. (2004). Henry Giroux's “Abandoned Generation” \& Critical Librarianship: A Review Article. Progressive Librarian, 23, 65-74.

Garcia, K. (2015, June 19). Keeping Up With... Critical Librarianship [Text]. Retrieved August 10, 2017, from http://www.ala.org/acrl/publications/keeping_up_with/critlib

Sifuentez, M. (2016). Of Forests and Fields: Mexican Labor in the Pacific Northwest. New Brunswick, New Jersey: Rutgers University Press.

Stephen, L. (2012). The Story of PCUN and the Farmworker Movement in Oregon. Rev. ed. Eugene: Center for Latina/o and Latin American Studies, University of Oregon. Retrieved from http://cllas.uoregon.edu/wp-content/uploads/2010/06/PCUN_story_WEB.pdf

Woken, D. (2014). Pineros y Campesinos Unidos del Noroeste (PCUN). The Oregon Encyclopedia. Portland: Portland State University and the Oregon Historical Society. Retrieved from https://oregonencyclopedia.org/articles/pineros_y_campesinos_unidos_del_noroeste_pcun/ 